\title{
The human condition of the nursing worker from the perspective of Hannah Arendt
}

\author{
Condição humana do trabalhador de enfermagem na perspectiva de Hannah Arendt \\ Condición humana del trabajador de enfermería desde la perspectiva de Hannah Arendt
}

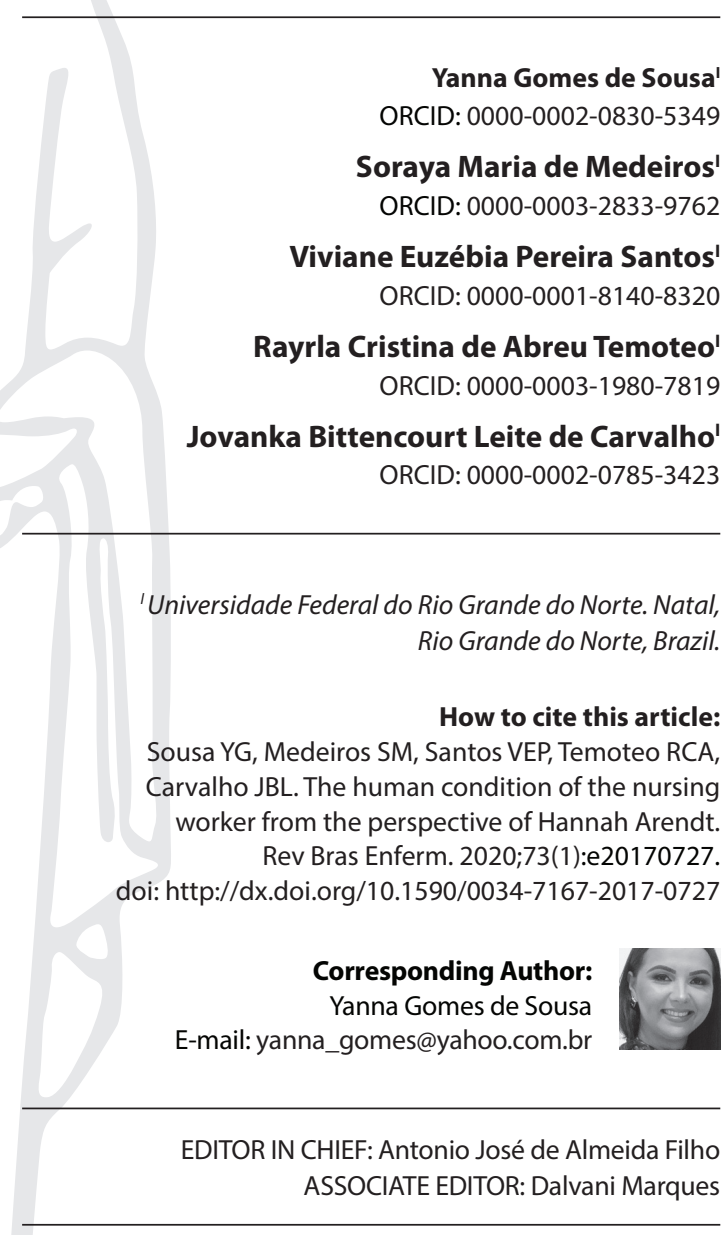

Submission: 10-18-2017

Approval: $10-13-2018$

\begin{abstract}
Objective: This study intends to analyze how the human condition of the nurse is established in the context of Psychosocial Care Centers (Caps). Method: theoreticalreflexive study, anchored in three essential parts: 1) Theoretical and philosophical conception of the human condition from Hannah Arendt's perspective; 2) The nurse's work in the Caps; and 3) Human condition to think about the work of the nurse. Results: in the context of the Caps, the work can be represented by the psychic significations; the work, through the production of nurses' practice of care; and the action by the relations established between worker and institution, worker and user. Final considerations: the understanding of the vita activa allows to reflect on the human condition of the nurse in their work context and (re) considers a better understanding about the impact of the work on the life of these mental health workers in the contemporaneity.

Descriptors: Philosophy; Nursing; Work; Mental Health Services; Occupational Health.
\end{abstract}

\section{RESUMO}

Objetivo: analisar como se estabelece a condição humana do enfermeiro no contexto dos Centros de Atenção Psicossocial (Caps). Método: estudo teórico-reflexivo, ancorado em três partes essenciais: 1) Concepção teórica e filosófica da condição humana na perspectiva de Hannah Arendt; 2) O trabalho do enfermeiro nos Caps; e 3) Condição humana para pensar o trabalho do enfermeiro. Resultados: no contexto de trabalho do Caps, o labor pode ser representado pelas significações psíquicas; a obra, pela produção da prática assistencial do enfermeiro; e a ação pelas relações estabelecidas entre trabalhador e instituição, trabalhador e usuário. Considerações finais: a compreensão da vita activa permite refletir sobre a condição humana do enfermeiro em seu contexto de trabalho e (re) considera na contemporaneidade uma melhor compreensão sobre o impacto do trabalho na vida desses trabalhadores da saúde mental.

Descritores: Filosofia; Enfermagem; Trabalho; Serviços de Saúde Mental; Saúde do Trabalhador.

\section{RESUMEN}

Objetivo: evaluar cómo se establece la condición humana del enfermero en contexto de Centros de Atención Psicosocial (Caps). Método: estudio teórico y de reflexión a partir de tres partes esenciales: 1) Concepción teórica y filosófica de la condición humana desde la perspectiva de Hannah Arendt; 2) El trabajo del enfermero en los Caps; y 3) Condición humana para pensar el trabajo del enfermero. Resultados: el contexto de trabajo del Caps, la labor puede representarse por las significaciones psíquicas; obra por la producción de la práctica asistencial del enfermero; y la acción por las relaciones establecidas entre el trabajador y la institución, el trabajador y el usuario. Consideraciones finales: la comprensión de la vita activa permite reflexionar sobre la condición humana del enfermero en su contexto de trabajo y (re)considera en la contemporaneidad una mejor comprensión sobre el impacto del trabajo en la vida de esos trabajadores de la salud mental.

Descriptores: Filosofía; Enfermería; Trabajo; Servicios de Salud Mental; Salud Laboral. 


\section{INTRODUCTION}

Hannah Arendt, in her book The Human Condition (1958), addresses the philosophical theme in direct relation to life, since it represents the characteristics of the existence of men in a given space and, without these characteristics, that existence would cease to be human. The human condition represented by the vita activa is constituted by three fundamental human activities: the labor, the work, and the action. Each of these activities corresponds to a basic condition for the life of men ${ }^{(1)}$.

Arendt analyzes the human being in their work dimension, in which the man is defined as a being that produces. Such analyses contribute to the development of a deep understanding of the human condition in the working environment and, consequently, in occupational science. We note that because it originates only from the analysis of man's work, occupational science cannot explain the man as homo faber, hence the difficulty of answering the anthropological question: "Who is the man?" He is a being that produces himself through labor ${ }^{(2)}$.

We should highlight that occupational science permeates a moment of historical transformations, represented by a dynamic development process, which over the course of time has undertaken to give a rational and scientific response to the health problems of workers, arising from their processes in their work locus. However, these responses made it possible to understand the work environment only in its statistical occupational definitions, which may lead to negligence of other issues ${ }^{(2)}$.

With a proposal of work based on the consolidation of an integral practice and distant from the reductionist assistance that disregards subjectivity, social, ethical, and humanistic commitment, the Nursing, from the outset of the Psychiatric Reform movement (PR), begins to (re)build its knowledge, care and, consequently, its technological advancement in institutions that substitute psychiatric hospitals.

This movement has influenced changes in the field of mental health care, resulting in the need to reorganize the work process of the professionals involved. Thus, nursing care in current mental health begins to require nurses to act as therapeutic agents, who have their practice consolidated through the nursing process (NP). It provides the nurse with the condition of assuming an autonomous position within the multidisciplinary team of mental health services and, as a result, qualification of nursing care in the context of the mental health offered ${ }^{(3)}$.

Nursing care applied in this perspective broadens the quality of care, encompassing clinical, social, political, and cultural issues with the possibility of deconstruction of a mental institution model and consequent deinstitutionalization and (re)construction of the dignity of life, citizenship, autonomy, and identity of the person with mental suffering. However, the context of change is not exhausted or crystallized because it is constantly changing in terms of work logistics, which implies distance from secular vices that isolated and segregated knowledge, suffering, and people ${ }^{(3)}$.

Thus, the change in the nursing practice is noticeable, whose object of care was the individual, seen until then as a sick person and excluded from any participation in their therapeutic process, since their actions were circumscribed and defined by the disease. On the other hand, the current historical context directs the focus of the nurse's assistance to the social reintegration of the person with mental suffering. In this context, insanity is considered an integrated social phenomenon as part of the person's existence. However, from the point of the worker/institution, the environment of the Psychosocial Care Centers (Caps) has been permeated by contradictions and a large problem intrinsic to the implementation process of these services, with inadequate infrastructure and lack of logistical support (sanitation materials, medicines, transportation). These challenges have had an impact on the configuration of work processes, the relationships established between the different actors, the satisfaction and the pleasure/suffering dynamics of the workers in the work environment.

Therefore, the relational dimension as a result of the confrontation subject $\times$ work in the work environment has repercussions on the worker's health and, consequently, on the human condition, since the labor practice can be seen as the cause of undesired suffering, painful, and humiliating toil. It can generate, however, pleasure as something that defines personal identity and validates the work and the worker ${ }^{(4)}$. For this reason, reflection on the evolution in the form of mental health care in the context of Caps is necessary, as it is a substitute service to the psychiatric hospital, as well the reflection on the quality of the working conditions offered to workers of these centers.

Considering that men are simultaneously singular and plural beings, and yet they are exposed to each other in a material context of relationships that underline the essential fragility of all existence, this study focuses on the labor, the work, and the action. It is defined from the place that is being analyzed, in this case the work of the nurse of Caps.

In this context, the work of political theorist Hannah Arendt The Human Conditionis is used as a reference to understand the multifaceted nature of life in the context of work. This study intends to analyze how the human condition of the nurse is established in the context of Caps.

\section{THEORETICAL AND PHILOSOPHICAL CONCEPTION OF HUMAN CONDITION FROM HANNAH ARENDT'S PERS- PECTIVE}

Hannah Arendt (1906-1975), German political philosopher of Jewish origin, addresses the human condition and its temporality. For Arendt, the human condition - which is not confused with the concept of human nature - is characterized by the vita activa (the human life that strives to do something) and corresponds to basic conditions for the life of men: the labor; the work (production of something new); and the action. These concepts comprise the circumstances of life encountered by men ${ }^{(1)}$.Thus, Arendt elaborates a philosophical anthropology that seeks to encompass the various human dimensions.

According to Arendt, labor is considered as the activity that leads men from birth to death in a rectilinear, circularly-shaped progression that follows the life cycle of the human body and, as long as there is life, never comes to an end. It is characterized by a biological process of the human body, whose spontaneous growth and metabolism are linked to the vital needs produced by labor to feed the life process. To labor is to produce consumer goods - to labor and to consume are two stages of the cycle of reproduction of biological life and are always producing life - and, since it corresponds to the condition of life itself, participates in 
its fatigue and pain, but also of the blessing or the joy of labor, which plays a very important role in modern theories of work ${ }^{(1)}$.

The work (production of something new) consists in the unnaturalness of human existence and produces the artificial world of objects, of durable things, being attributed to the homo faber. Its human condition is to belong to the world. The man creates a world of their own through the production of the artificial, characterized by culture, by estrangement to their purely material condition.

Action is the activity that is exercised directly among men, without the mediation of objects or matter, and corresponds to the human condition of plurality and occurs in a purely intersubjective sphere. Hence the complete break from the purely natural world. Intersubjective relationships are characterized by 'transcendence'. It is only in this environment of plurality made possible by the exchange of rational subjects that political life can emerge, the central object of human condition ${ }^{(1)}$.

For Arendt, labor, work, and action correspond to an aspect of the human being, animal laborans, which produces goods with a fixed duration. The goods are consumed in order to preserve the species, so they are related to the maintenance of life. Homo faber is the great producer of the human artifice on Earth and director of the objects that exist in the world. Its activity of manufacturing is the same, regardless of the historical period: through the mastery of technique, it generates an inexhaustible production of wealth, called production-consumption scheme ${ }^{(1)}$.

\section{THE WORK OF THE NURSE IN PSYCHOSOCIAL CARE CENTERS (CAPS)}

The Nursing work dominates a field of knowledge that gives competence to care for people throughout the process of living and dying. Thus, caring pervades three basic dimensions: a) Caring for individuals and groups, from birth to death; b) Educating and researching, which involves the education intrinsic to the process of caring, permanent education in the work, formation of new professionals and production of knowledge that subsidize this process; and c) The administrative-managerial dimension of care space and participation in the management of health and institutional care $\mathrm{e}^{(5)}$.

In the first decades of the 20th century, psychiatric nursing care came from the knowledge developed about and inside the psychiatric hospital, associated with manual work, characterized mainly by surveillance, observation, and control of patients' behavior through techniques that involved clinical care and measures of chemical and physical containment ${ }^{(6)}$. This assistance context reinforced the pathologization and reproduction of the exclusion of the person with mental suffering through the execution of practices anchored in violation of human rights. However, the changes in the way of constructing practices that subsidize the nursing profession were possible from the assumptions of the Psychiatric Reform.

The emergence of the Psychiatric Reform movement in the 1980s and 1990s represented the struggle for changes in the approach to insanity and its forms of treatment, as well as legal/normative and cultural aspects involved. In this scenario, the Nursing began to act in institutions, replacing the asylum model from the first Psychosocial Care Center (Caps), which emerged in the city of São Paulo in 1987. In parallel to the emergence of Caps, the Nuclei for Psychosocial Care (Naps) were also implemented, which began to organize the demand for mental health care in the territory, with Caps being the gateway to the Psychosocial Care Network (Raps).

From this perspective, it is important to highlight that the nurses' work is part of an extended practice of care that transcends the traditional resources that subsidized asylum practices. Thus, based on a conception of interdisciplinary teamwork, nursing care is based on new forms of care in mental health, which respect the individual's singularity and assume a critical-reflexive therapeutic attitude, from a humanistic perspective ${ }^{(6)}$.

The resignification of nurses' work implies the creation of spaces that promote the biopsychosocial and cultural rehabilitation of the individual with psychiatric suffering. Thus, the work is organized autonomously by means of the implementation of the nursing process, which allows a wide range in the evaluation of the health status of the person with mental suffering, and, collectively, through the construction of the SingularTherapeutic Project (PTS) with the other members of the team, the user and their families, and the formation of groups and workshops for therapeutic purposes. In addition, the nurse also provides matrix support, providing support to family health and management in crisis situations, and participates in the reinsertion through work, home visits, and family care ${ }^{(7)}$.

The dynamic work of the nurse, in this setting, is important to highlight. A dynamic work mediated by a process of building possibilities, skills and competences in the daily routine of the user, so that psychosocial rehabilitation and social reintegration become possible. From this perspective, the nurse acquires a professional identity as a member of the interdisciplinary team, which favors the construction of skills equivalent to the know-how of the profession, with the development of care plans, with support in decision-making on issues inherent to their assignments in the field of mental health ${ }^{(7)}$.

Although we are facing a logic that signals ruptures and overcoming of the asylum model, there is still a reflection to be made on what is announced as reform and what is effective as a nurse's job, as in the current situation of Caps services, the teams of these centers have listed barriers that jeopardize the solidification of the Psychiatric Reform. Among them, the following stand out: the lack of implementation of PR in the practices of services and professionals; the difficulty in articulating with the other points of health care of the territory, including the actions of the Family Health Strategy Teams (ESF), and the working conditions hampered by the lack of human and material resources to operationalize inclusion activities ${ }^{(8)}$. These problems cause consequences to the quality of nursing care provided to the individual with psychiatric suffering. Such problems may be effect of a reform process with insufficient managerial and policy support to effect, within the scope of services, the construction of a network of psychosocial attention committed to the effectiveness of its guidelines.

\section{THE HUMAN CONDITION TO THINK THE NURSE'S WORK}

In the conjuncture of Caps, the concepts that sustain the human condition of vita activa approached by Arendt can be applied to the nurses'work process, since labor, work (production of something new), and action are present in a concrete way in this work environment.

The labor is represented by the material dimension of the nurse, who as a mental health service worker lives in social relations and in the interfaces between singular and collective, the construction of a practice that is established through relationships with other 
professionals in the team, users, family members and service managers. In this work/relational context, subjectivity, motivation and desires appear as central, able to produce pleasure and/or suffering, and are derived from the internal dynamics of situations and forms of work organization, creation of subjective relationships and power in the team, conducts and actions of workers ${ }^{(4)}$.

Some challenges permeate the work of the multidisciplinary teams of Caps: conditions of physical infrastructure, materials, equipment and inadequate medicines; insufficient human resources; and difficulties inherent to the management of services, which restrict their functioning and make it difficult to consolidate the changes proposed by the new model of mental health care ${ }^{(9)}$. In addition, these difficulties make the nurse's work exhaustive, with emphasis on the psychiatric meanings, which generate negative feelings and, therefore, changes their emotional state. It can cause consequences to the body, such as fatigue, irritability, depression, and summative states, possibly leading to illness and, consequently, contributing to the physiological degradation of the professional ${ }^{(10)}$.

In this way, the nurse seems to be subject to the portrait of the animal laborans in its essence, from the "body that mixes with the other" and seems overwhelmed by doing, working to supply needs and demands, nourishing only the vital process. And in the scenario of Caps, this may appear from two perspectives: in the first, the nurse works to support the other - in this case, the nursing care provided to the person with mental suffering; and, in the second, the nurse works in exchange for salary, without greater prospects of acknowledgment.

However, there is also the search for pleasure and the escape of displeasure, which constitute a constant aspiration for the nurse, due to the requisites instituted in the process, in the relationships and in the organization of work. Pleasure experiences arise from the amalgam that work brings to the body. Psyche and interpersonal relationships are evidenced through gratification, fulfillment, acknowledgment, freedom and valorization in work ${ }^{(4)}$. In this work reality, the homo faber appears as subject of fabrication that assumes value in the life of these subjects. For Arendt, there is a period of relief and brief joy that follows the execution and completion of work, just as pleasure is concomitant to the functioning of a healthy body ${ }^{(1)}$.

The work, another component of Arendt's human condition of vita activa, is effective through the production of a care practice implemented by the nurse that seeks the development of new paths of nursing care, based on actions with health promotion, emphasis on new pathways of a more vivid and human care and, thus, more effective. Nursing care promoted by nurses in substitute services stands out because of the need to build bonds, to embrace suffering and to construct a creative and supportive practice that favors qualified listening and, consequently, improvement of the quality of life of users.

As regards the third human condition, action, it is understood to be characterized by the relationships established between worker and institution, in which interpersonal and biopower relations between management and workers are involved; by social ones; and the interfaces between singular and collective, work and mental health and worker-user, in which continued care takes place and produce psychiatric meanings and the construction of subjective and intersubjective relations in the worker.

The action allows nurses the possibility of creating meanings of their own objective reality of work from the configuration constituted in the webs of human relations established in these centers, with the perspective of being given the ability to install novelties in the work process, with rupture of boundaries and borders and the creation of nurse-users, nurse-manager and nurse-other professionals bonds ${ }^{(7)}$.

In this sense, labor, work, and action proposed by Arendt can serve as theoretical conceptualizations for a deeper description of the human and occupational condition of the nurse who works in Caps who define themselves as beings constructed in three dimensions, from human activity. Their body needs work to continue to be human, integrated. By the work of their psyche, the nurse produces the artificial, builds a world parallel to the natural, of which their body is part. Finally, in establishing intersubjective relationships, they transcend themselves toward the other. Therefore, although the nurse develops by activity, in its various dimensions, the first two conditions - labor and work must guide the latter, the action, creating a properly human world in which the human condition of the nurse is effective.

And it is at this locus that occupational science must present its capacity not only to take care of health problems arising from work but, above all, to propose ways of avoiding such problems. A vision made possible by philosophy, and especially treated here by Arendt's reflection, which allows occupational science to appropriate a multifaceted view of the human condition of the nurse, with a view to a better and deeper understanding of the impact of work in the lives of these workers.

Thus, as a valuable contribution to occupational science, the understanding of the vita activa allows a reflection on what happens in the world of the nurse's work and calls us to (re)consider in the contemporaneity the human condition from the work context and its new perspectives. For Arendt, not only the activities executed during the work, but also the consequences of human activity are relevant to the understanding of the phenomena that condition the vita activa ${ }^{(2)}$, represented in (Figure 1).

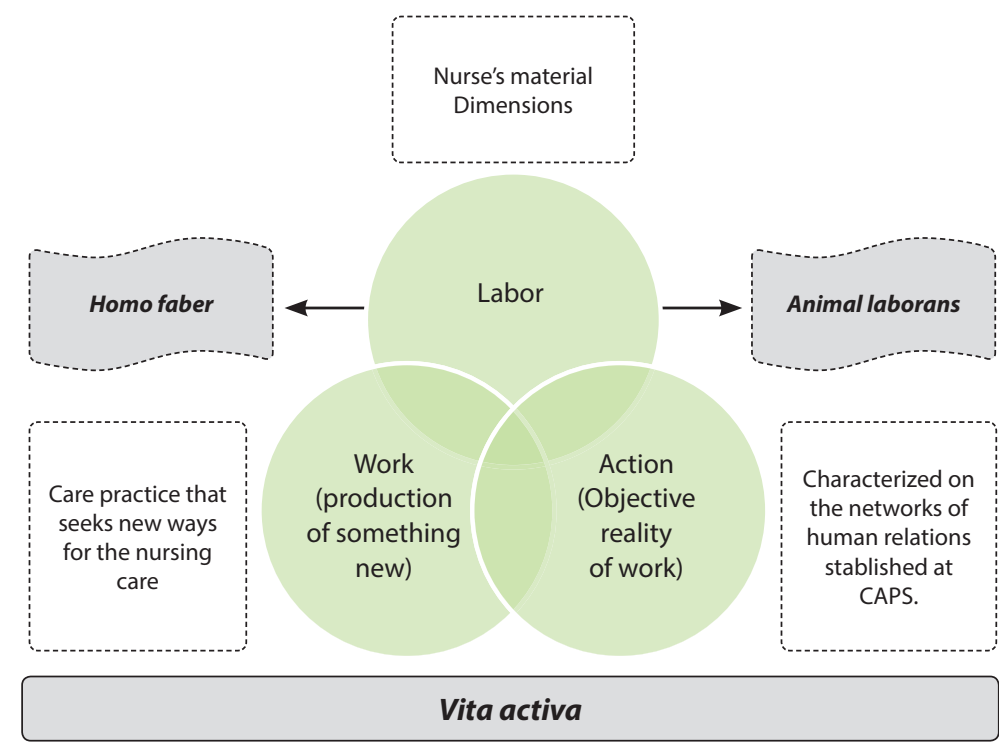

Figure 1 - Human Condition of the work of the nurse who works in the Psychosocial Care Center (Caps) 


\section{FINAL CONSIDERATIONS}

The vita activa in Arendt's thinking is presented as a possibility of interrelationship with the working context of Caps, since the nurse is a biological being, who acquires the necessary means for the continuity of their life with their work. This professional, through their work, transforms the natural world, transcending it, creating an artificial world, which is the search for the development of new paths of care.

Finally, the nurse is a being of action that not only has the capacity to transform the natural world into artificial, but to create a new one - the cultural, intellectual world -, which configures a dimension capable of thinking what is being done, including rethinking it. What is revealed not as subjectivity, but as intersubjectivity. The relationships established between the nurse and their patients make the construction of this "new world" possible. Thus, the nurse's work, analyzed from the philosophical perspective of Hannah Arendt, also allows to visualize a more comprehensive conception on issues inherent to the field of nursing in the context of Caps and the consequent contribution to the occupational science.

\section{REFERENCES}

1. Arendt H. A condição humana. Rio de Janeiro: Forense Universitária; 2013.

2. Jansson I, Wagman P. Hannah Arendt's vita activa: a valuable contribution to occupational science. J Occup Sci. 2017;24(3):290-301. doi: $10.1080 / 14427591.2016 .1277780$

3. Garcia APRF, Freitas MIP, Lamas JLT, Toledo VP. Nursing process in mental health: an integrative literature review. Rev Bras Enferm. 2017;70(1):209-18. doi: 10.1590/0034-7167-2016-00314

4. Dejours $C$, Abdoucheli E, Jayet C. Psicodinâmica do trabalho: contribuições da escola dejouriana à análise da relação prazer, sofrimento e trabalho. São Paulo: Atlas; 2015.

5. Pires DEP. Necessary changes for advancing nursing as caring science. Rev Bras Enferm. 2013;66(esp):39-44. doi: 10.1590/ S0034-71672013000700005

6. Esperidião E, Silva NS, Caixeta CC, Rodrigues J. The psychiatric nursing, ABEn and the Scientific Department of Psychiatric and Mental Health Nursing: progress and challenges. Rev Bras Enferm. 2013;66(esp):171-6. doi: 10.1590/S0034-71672013000700022

7. Pinho ES, Souza ACS, Esperidião E. Working processes of professionals at Psychosocial Care Centers (CAPS): an integrative review. Ciênc Saúde Colet. 2018;23(1):141-52. doi: 10.1590/1413-81232018231.08332015

8. Nóbrega MPSS, Domingos AM, Silveira ASA, Santos JC. Weaving the West Psychosocial Care Network of the municipality of São Paulo. Rev Bras Enferm. 2017;70(5):965-72. [Thematic Edition "Good practices and fundamentals of Nursing work in the construction of a democratic society"] doi: 10.1590/0034-7167-2016-0566

9. Clementino FS, Miranda FAN, Martiniano CS, Marcolino EC, Pessoa Júnior JM, Dias JA. Assessment of Organizational Structure of Centers for Psychosocial Care in the city of Campina Grande, Paraíba State. Rev Bras Ciênc Saúde. 2016;20(4):261-8. doi: 10.4034/RBCS.2016.20.04.01

10. Dias GC, Furegato ARF. Satisfaction in, and impact of work on, the multidisciplinary team in a psychiatric hospital. Rev Enferm UERJ. 2016;24(1):e8164. doi: 10.12957/reuerj.2016.8164 